بالة المشرة

\title{
The Japanese Muslim women and the Teaching of Islam as a Contemporary Issue
}

Prof.Dr. Junya Shinohe ${ }^{(*)}$

I would like to express my sincere gratitude to Dr. Muhammad Othman Al-Khashat (أ.د./ محمد عثمان الخشت) , President of Cairo University, Dr. Najala Rafat Salim (أ.د.//نجلاء رأفت سالم), Director of Center for Oriental Studies, and all those concerned for giving me this opportunity.

We share as our theme "Woman in Religions" this time, which, to me, is by no means an easy topic to discuss for two reasons. For one thing, I lack the experience of, hence impression or feeling about, being in the position that women have put or stood in their political and social life, for I belong to a different gender. In addition to that, the theme often involves discussion about women's rights, which is the aspect that are most commonly used by the West when they try to criticize Islam:

Islam does not allow a woman the right to divorce her husband.

Islam forbids a woman to go out without wearing a scarf.

There are many restriction in Islam, which leads the West to conclude that it is an old religion, not a suitable one in the modern age. From such a view I have tried to distance myself, and in this paper I would like to introduce some of the views toward Islam expressed by Japanese Muslim women today by analyzing their books and other writings. I would also like to introduce my own experience in teaching at university.

Japanese Muslim women have always tried to understand Islam mostly through their marriage life parenting in Japan, their children being the $6^{\text {th }}$ or

\footnotetext{
* Prof. of School of Theology Doshisha University - Kyoto, Japan
} 
$7^{\text {th }}$ generation (The $1^{\text {st }}$ generation is those who were born before 1944). They also help and learn from each other in their regular study meetings. Some of them have studied Arabic languages, Quran, and Fiqh in the Middle East countries, and so they are able to tell whether some information or idea they hold is from Quran, from Sunna or from some personal/private views of the cotemporary Islamic scholars expressed in their fatwa (judgement of the Islamic jurisprudence).

In the course of presenting my argument, I would also like to mention how Japanese people have kept their interest in Islam and have understood Islam since the $7^{\text {th }}$ century by presenting my analysis on the topic, which hopefully would explain clearly why Yoshida Shōin, one of the masters greatly respected among the leaders of Meiji Restoration, was attracted to the elements in the teaching of Islam. Shoin and his followers established the foundation of the modern state of Japan that lasts to this day.

From here on, I will introduce with my own analyses some of the books written by Japanese Muslim women.

【No.1】

Kawata, Naoko (2004) "Introduction to Islam by a Japanese Muslim Woman"

203 pages, Tukubanesha, Japan

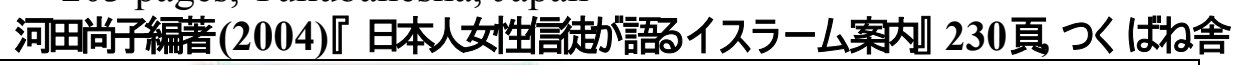

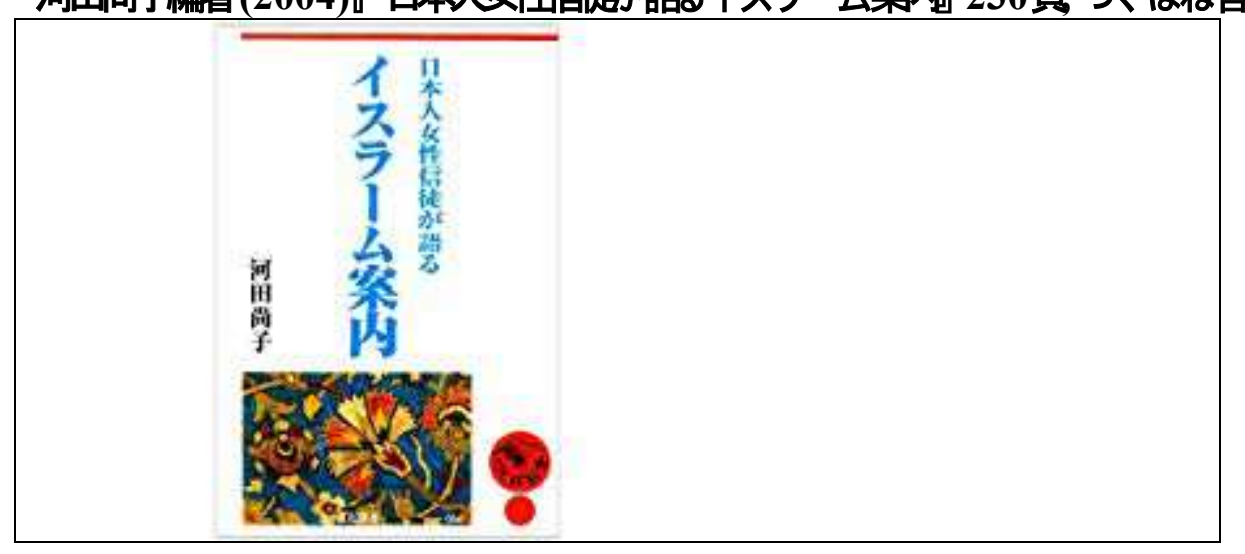

The author, Kawata, became a Muslim in around 1997, when she was about 40 years old. She realized that morals and ethics in Islam are not different from those in Japan. For her, Islam was a religion that adds something good to her life and one that improves her life. She also found that 
رسالة المشرة

5

few Japanese seem to share her view or thoughts, and so she wrote this book as an introduction of Islam for the Japanese.

In the book, Kawata explains about the beliefs of Islam (Iman), the Five Pillars of Islam, how to observe Shariah in one's daily life, mainly focusing on the prohibition of drinking alcohol and eating pork. These topics are often covered in other books that are intended to introduce Islam in Japan, but few, if any, of them cover the concept of Tawhid, which is dealt with in this book.

In her attempts to explain the concept of Tawhid in her book, Kawata quotes a story by a famous Japanese poet and writer of children's stories, Kenji Miyazawa. She does so in order to express that Tawhid in Islam means far more than the religion being monotheistic but that the point lies in its avoidance of worshipping anyone or anything beside Allah, even when there is some association between them and Allah.

The title of the story Kawata quotes is "The Night of the Milky Way Train," a work of fantasy literature by Miyazawa for children published in 1934;

"What kind of God is your God?" asked the young man with a smile.

"I don't really know; all I know is that there's only one real God."

"Yes, of course there is only one real God."

"No, what I mean is that there is only one true, real God. (Kawata pp.35)

Most Japanese people understand Islam as a monotheistic religion like Judaism and Christianity. And yet they do not know exactly what it was or is that separates Islam from the other two.

Islam, brought by Muhammad PBUH, reconstructed the Ibrahim belief, which, by that time, had been distorted by his people who came to worship not only Allah but also other associated existences.

The story by Miyazawa quoted above depicts how one can or does avoid Shirk. The words of the young man shows that he is trying to find who God is by logically thinking. On the other hand, Giovanni believes in the only one true God without, or beyond doubt or comparison/relativism of any sort. He is seeking for the one and only, true God, not as some logical consequence. He naturally and purely seeks for such God as a result of his being.

The author, Miyazawa, was a pious Buddhist of Nichiren School. Because of that, and in spite of not being a Muslim, he believed in the only one true existence to whom all people would return.

Naoko Kawata realized that at the core of Islam lies the avoidance of Shirk, which is essential in keeping belief in Allah. Comparison between Islam and polytheism is not necessary here, contrary to what many Japanese 
scholars in the religious studies and other researchers have believed and carried out.

Muslims tend to say that Islam is the true religion and Christianity is not. This may be according to the last two verses of the $1^{\text {st }}$ chapter of Quran. However, the point of the verses is not that Judaism and Christianity are "wrong religions." The verses provides a lesson for us about our belief by giving us the past examples where wrong beliefs were involved.

The same holds true in discussing the Christian doctrine of the Trinity. It seems to me that it was an effort made in vain to try to connect God and the world, hoping to strengthen one's belief by resorting both to reason and to emotion.

In her book, Kawata also discusses polygamy of Islam in her book, quoting some verses in Quran. However, she seems to be confused on this topic, which is probably because she lacks knowledge of fatwa by the Islamic Jurists. .

The Muslim society in Japan is also discussed in the last chapter of the book (about marriage between Japanese women and foreign Muslims and social interaction among Japanese Muslim Women).

【 No.2】

Kawata, Naoko (2011) "Islam and Japanese Women," 250 pages, Kokusho Kankoukai, Japan

河田尚子(2011)『イインームと 女性』250頁、国書刊行会

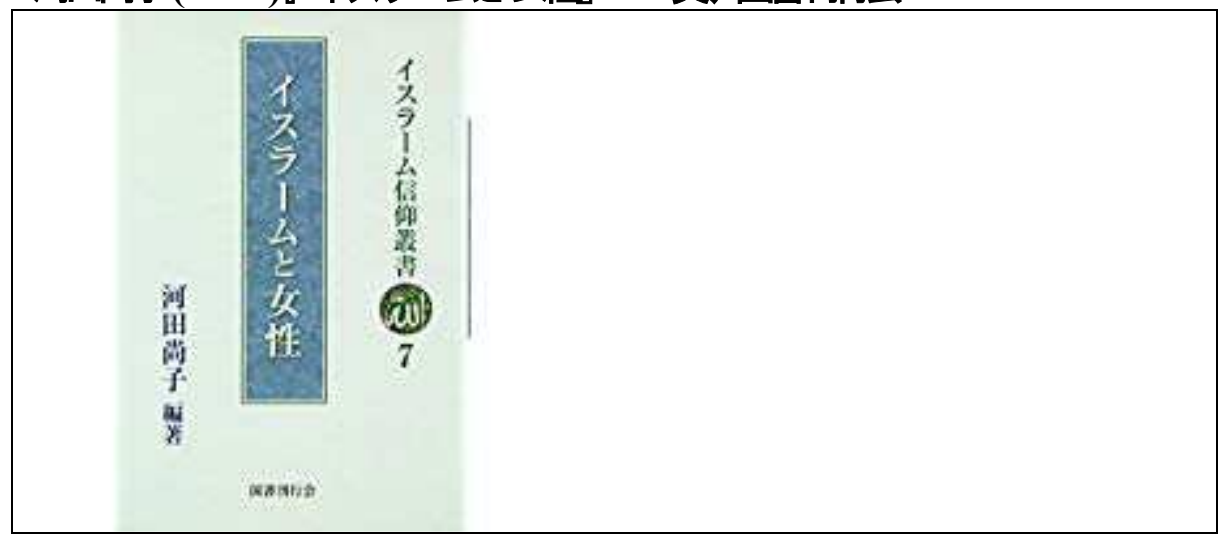

In this book, a Muslim husband and a Muslim wife, Yohei and Tomoko, write about married Japanese Muslim couples and Japanese society. Yohei, the husband (1984-) is a full-time university lecturer. Tomoko, the wife (1981-) is an editor of Muslim Shinbun (newspaper), and both of them are 
رسالة المشرة

7

intellectuals. Their understanding and views on Islam is much influenced by their position in the Japanese society that make them feel somewhat left out.

They think that the role assigned to them as Muslims is to awake consciousness in Japanese people, for Japanese people in the communities they live, including their workplaces, will know their religion through them. By quoting verses from Quran, they assert that being Japanese and being Muslim at the same time creates contradiction;

[8.60] And prepare against them what force you can and horses tied at the frontier, to frighten thereby the enemy of Allah and your enemy and others besides them, whom you do not know (but) Allah knows them; and whatever thing you will spend in Allah's way, it will be paid back to you fully and you shall not be dealt with unjustly.

Chapter 8:60

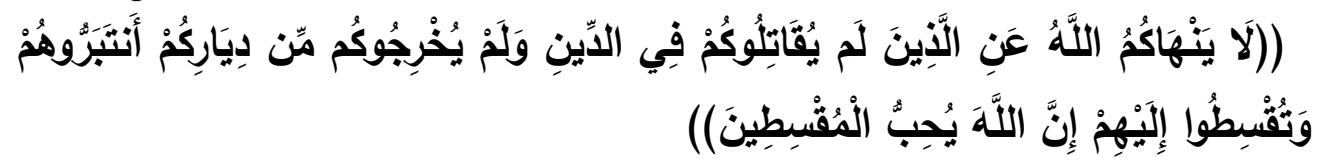

[2.150] And from whatsoever place you come forth, turn your face towards the Sacred Mosque; and wherever you are turn your faces towards it, so that people shall have no accusation against you, except such of them as are unjust; so do not fear them, and fear Me, that I may complete My favor on you and that you may walk on the right course.

Chapter 2:150

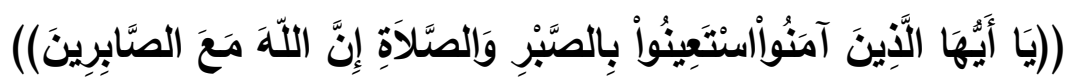

[3.110] You are the best of the nations raised up for (the benefit of) men; you enjoin what is right and forbid the wrong and believe in Allah; and if the followers of the Book had believed it would have been better for them; of them (some) are believers and most of them are transgressors

Chapter3:110

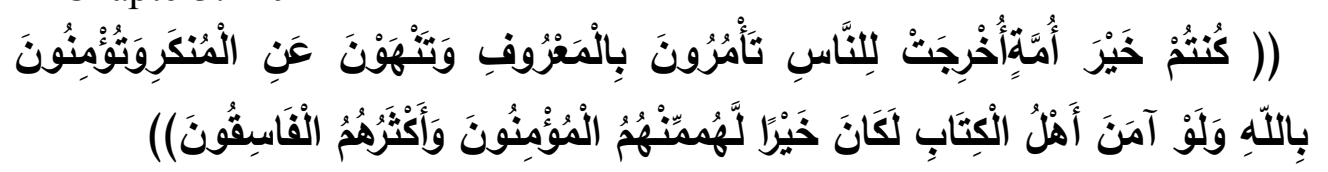

(pp.77-104)

My impression is that they are using Islam as a means to attack the custom and history/tradition in Japan. Yet they do not necessarily act openly in that direction, so their Islam remains only within their mind as merely an inner, political attitude which neither comes out to be expressed in their way 
of life or behavior nor takes into consideration their real life in the place they live.

The couple, Yohei and Tomoko, belong to the generation succeeding to the one Kawata belongs to, who wanted to be Muslim to add something good to her life and who did not find contradiction in being a Muslim and living as a Japanese in Japan.

Kawata thinks that belief, whatever it is, is based both on intelligence and on emotion together and that it is impossible to separate the two.

Yohei and Tomoko saw Japanese society and the Japanese as being in the darkness, while they live in the light of Islam. Their Islam is merely an imagined Islam - Islam imagined and only existing in their minds. It is easy for anyone to speak of Islam using verses in Quran, by which other Muslims judge the person as being an enthusiastic Muslim. Some, especially young people, may want to be accepted by the society, and some may be hoping to be respected by others, for which purpose they can using something that attracts people's attention or respect. And for this, they may turn to some of the elements in Islam.

Yohei, the husband, wears beard, and the wife hijab, Arabian cloth. It seemed to me that they are trying to be respected in Japanese society, being an idea model of a Muslim as often shown in books about Islam. In fact, the husband has had no experience of living with Arab Muslims in places like a university dormitory or with Arab Muslim family.

A Japanese scholar once said that the ideal image of Christianity maintained by the Japanese had never existed in Europe. The same is true of Islam. Many Japanese people, including Japanese Muslims, may have an ideal or conceptual image of "true" or "pure" Islam in their minds. Yet the place they should search for clues to the true understanding of Islam is not their own minds but Quran, and also knowledge of $\mathrm{F}$ fiqh is also required to adapt the teaching of Islam to the real life. How to adapt the teaching of Islam to the real life is more important than the conviction and determination to change the present society into the Islamic society by violence.

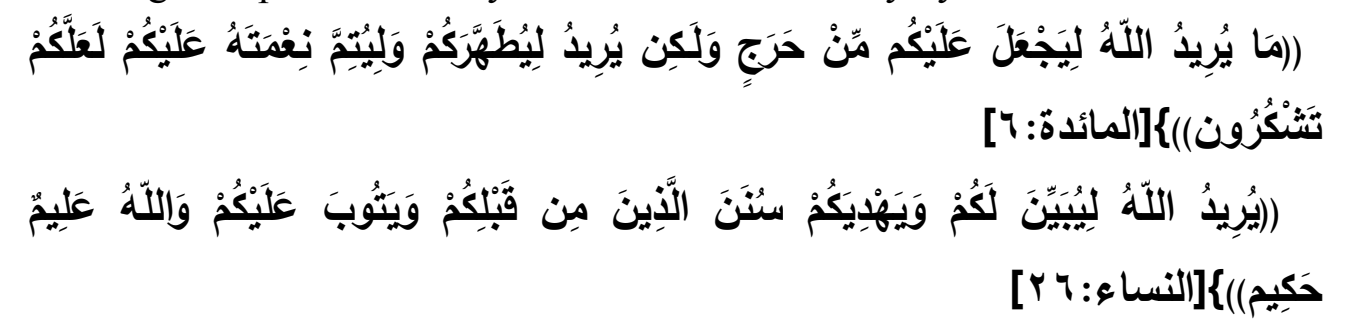


بالة المشرة

9

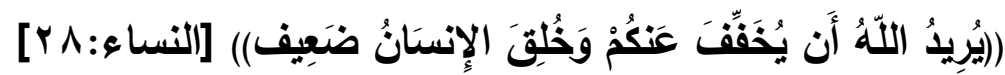

【No.3】

Kobayashi, Akiko (2015) "When Islam Meets Japan - Its History and Future -," 316pages, Gendai Shokan, Japan

小村明子（2015）『日本とイスラームが出会うとき

その歴史と可能性』316頁、現代書館

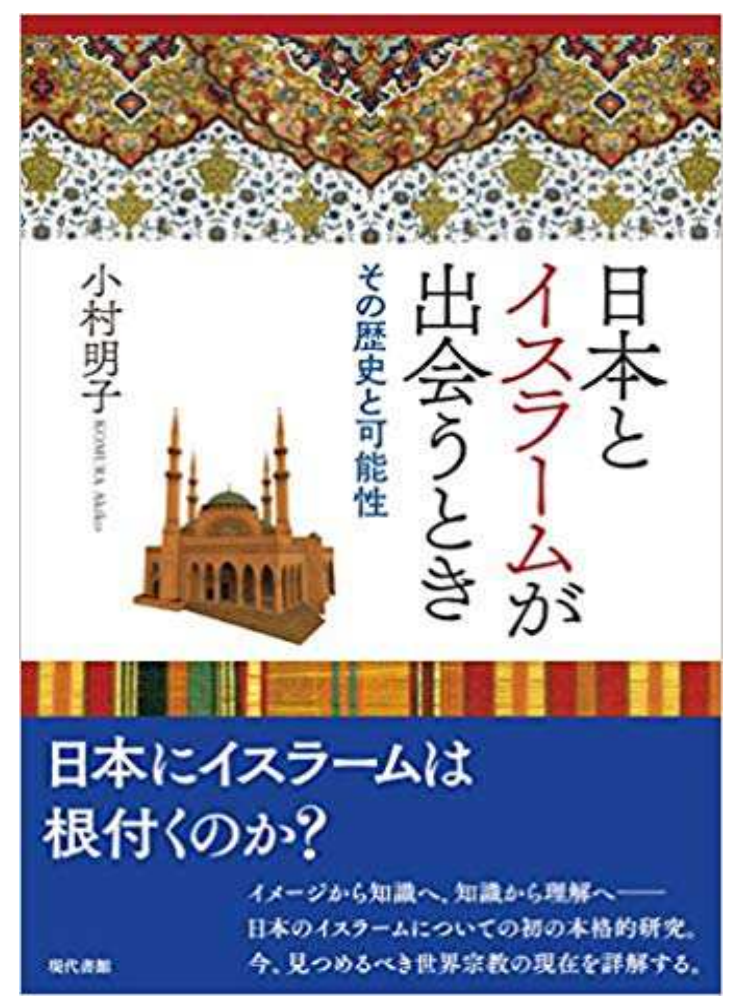

Kobayashi Akiko is about 40 years old, or so I estimate, though it is not mentioned in her book. She is not a Muslim, She is a researcher who interviews Muslims in Japan in Mosques and other places where Muslims gather and meet each other. She has read old books about Islam in Japan, although I have noticed some mistakes which were probably because her view on Islam is influenced by the common views on religions among the Japanese that are widely shared in the country after WW II (1939-1945). 
Japanese people kept their religious traditions even after the surrender after WW II, on which the US forced the country to wipe out elements of any kind that supported Empire of Japan.

Kobayashi was taught in her school days about a principle of the separation between the regime, or the politics, and the religions. Her discussion is based on the view that believing in Muslim must go against Japan and hence a true Japanese Muslim must also be against Japan and can never be a patriot.

Ahmad Ariga (1868-1946) was the $2^{\text {nd }}$ generation Japanese Muslim, who converted from Christianity. He translated Quran to the Japanese language, and wrote many booklets about Islam. He participated in building Kobe Mosque built in 1935. 45 Japanese converted to Islam by him according to his diary, which is stored by his grandson. He was a Muslim and a patriot. $\mathrm{He}$ was an activist supporting Asian people, through the Japanese government's policies, in achieving their independence. He had no doubt that it was possible for the Emperor of Japan to convert to Islam while also maintaining Japanese culture and history.

The following two photos are of Muslim tombs in Kobe Municipal Foreign Cemetery. There is a gravestone for Ahmad Ariga.

An Egyptian Imam, Ariga's grandsons and a daughter, and I prayed for him in the memorial ceremony setting a new tombstone for Ahamd Ariga $(2018 / 11 / 18)$.

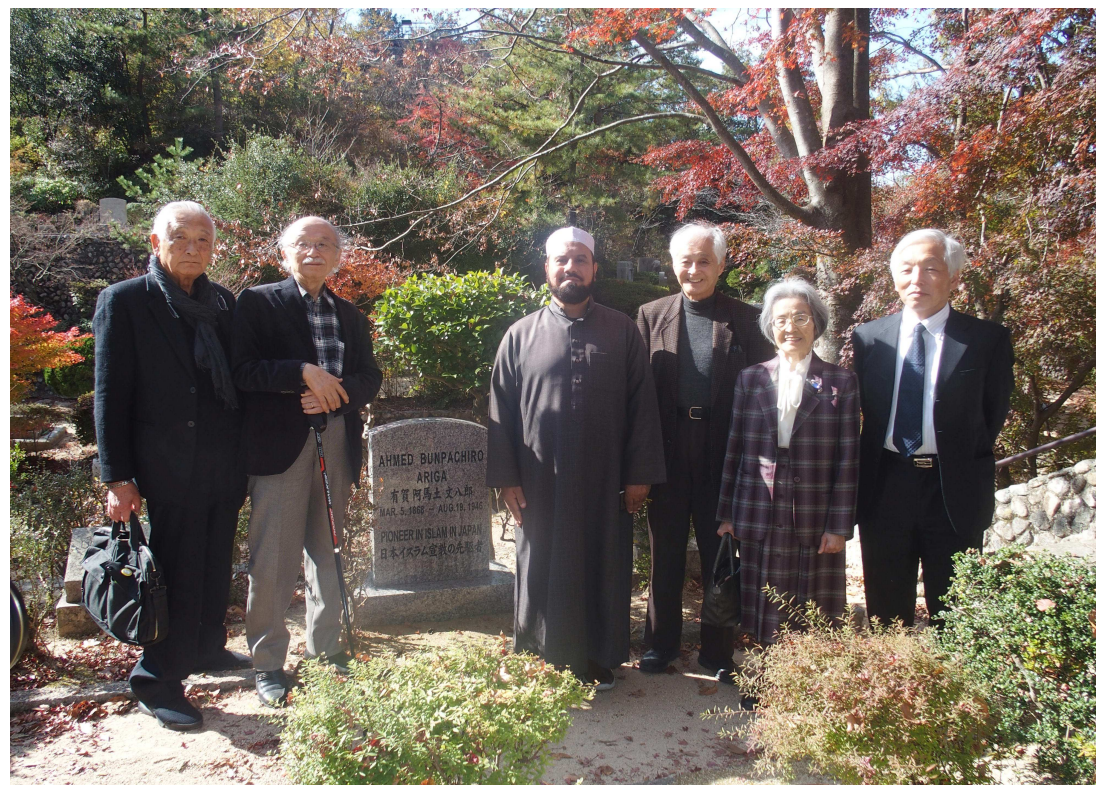


رسالة المشرة

11

【No.4】

Skurai, Yukiko (2003) “ Islamic Society in Japan,” 223 pages, Tsikumashobou, Japan

桜井啓子(2003)『日本のムスリム社会』233pages,筑摩書房

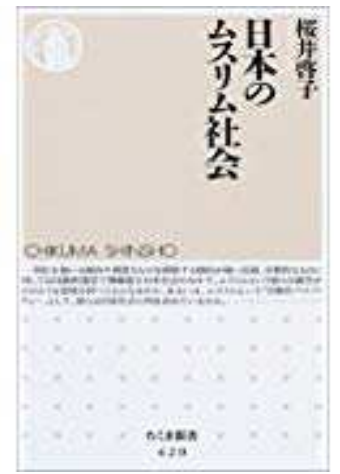

She (estimated to be 58 years old) is not a Muslim. She discussed foreign Muslims in Japan around from 1986- 2000, when Japan was experiencing a bubble economy and a lot of foreign labor power came into Japan. This resulted in the increase in the number of the foreign Muslims in the country. Some of them got married to Japanese women who converted to Islam through their marriage. This book discusses foreign Muslims in Japan only in that specific period of time although the title of the book is "Muslim Society in Japan," not implying any period in the history of Japan. information.

She did not contact Japanese Muslims or foreign Muslims for inside

【No.5】

Sato, Kenei (2015) "Believing in Islam in Japan" 216 Pages, Bungei Shunjyu, Japan

佐藤兼永

(2015)『日本の中でイスラム教を信じる』216頁、文藝春秋

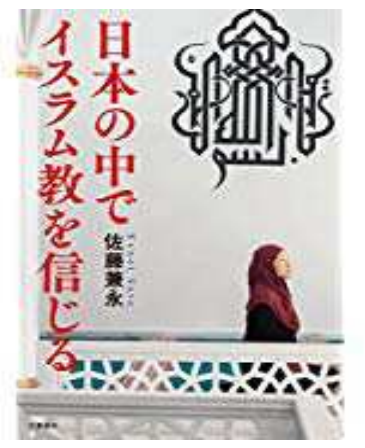


The author, Sato Kensui, is a journalist. He is not a Muslim. Through his social interaction with Muslims in Japan, some questions came up to his mind about Islam, and in this book he deals with them. We can easily find common views on Islam that the ordinary Japanese people tend to have, which can also be found in many other older books published before this one in Japan, though with a few exceptions.

For example, he askes why Muslim women put on Hijab. They answer that a woman is a beautiful creature, so beautiful that she needs to be hid, quoting a verse from Quran 24:31 Al-Nur. He says that it is not clear, what is فُرُوجَهُنَّن in parts of the body (p.48).

It requires knowledge in Islamic jurisprudence although there are different opinions among Mazaahib (Islamic schools) about women's hair of head. In addition to that, the word "Hijab" does not mean women's scarf but curtain (sitar) in Al-Nur. He complains that most Muslim women put on hijab without reading or understanding Quran. He goes on to discuss the point, trying to get views from a Japanese Muslim woman why Japan Muslim women wear scarfs. She answers to his question saying wearing hijab makes her happy because people around her would see her and pay an attention to her (pp.133-134).

This book is valuable in that he discusses Islam in Japan with a Japanese Muslim woman who converted to Islam when she was a university student. Her husband is a born-Muslim staying in Japan. She has strong relations with other Japanese Muslim women as well as with born Muslims through her husband. Being a mother, she is also on good terms with Japanese Mother Muslims. Islam in Japan has reached its $6^{\text {th }}$ generation. They know Arabic well and can read Quran and Tafsir in Arabic, and they can discuss and express their opinions about Islam. 
رسالة المشرة)

13

\section{【No.6】}

Qaradawiy, Yusef (2012) “ Islamic Jurisprudence for Minority Muslims" translated into Japanese, 271pages, Japan-Saudi Association, Japan

ユーセフ・アルニカラダーウィー

(2012)『マイノリティ・ムスリムのイスラーム法学 271頁、日本サウジアラビア協会

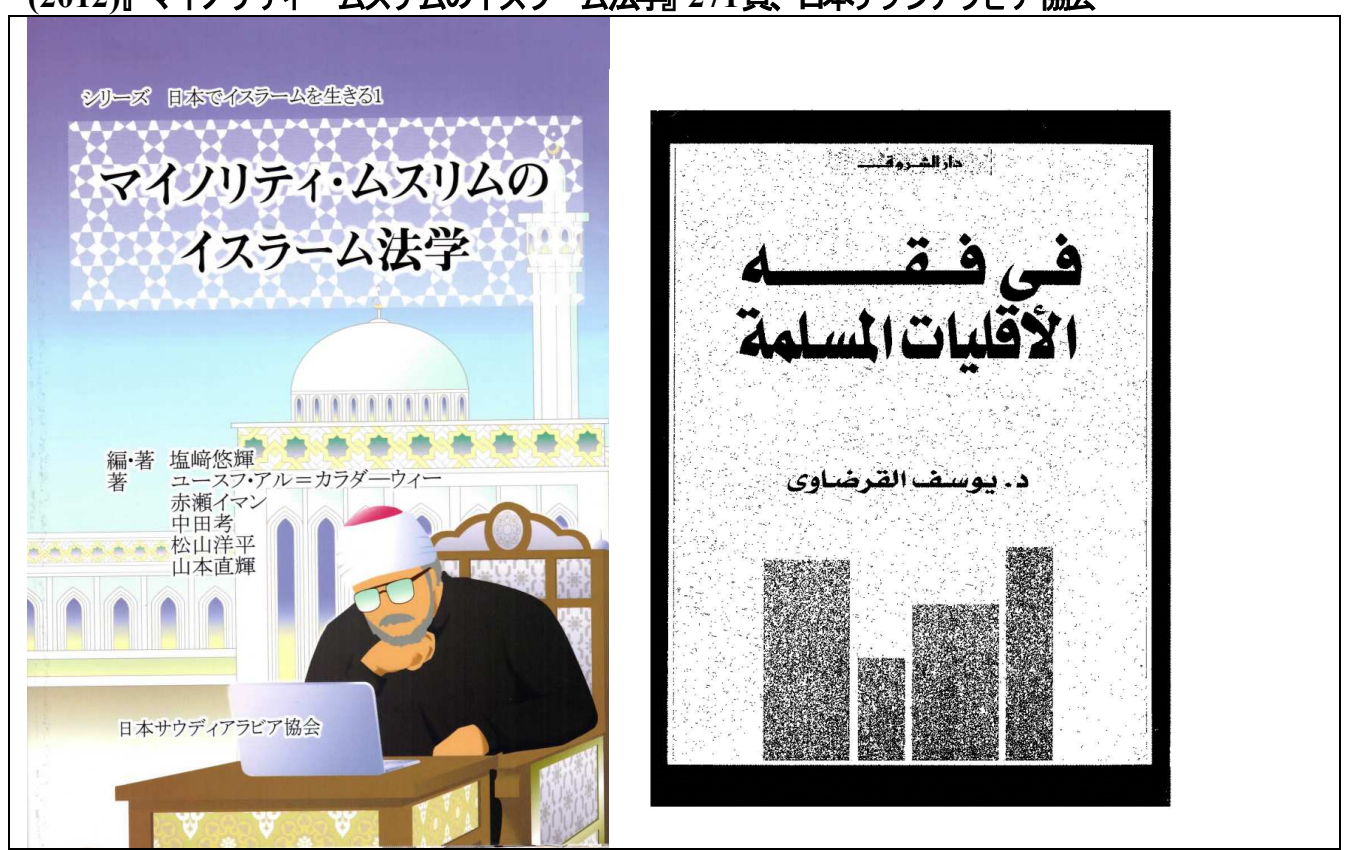

Dr. Yusef Qaradawiy has dealt with many issues for Muslims in the West and has issued his fatwas after introducing fatwas by the prominent scholars of Islamic jurisprudence. His fatwas have always served as response to the need of our society. His wording is quite strong and energetic.

In this book, four Japanese Muslims give their comments. One of them is very honest in expressing her opinion, making clear the difference between the image of the West shown by Dr. Qaradawiy and her own experience of living in the society in the West and of interacting with European Muslim friends.

Her name is Iman Akama, and she studied Islam in Arabic language in Damascus but she did not know about this prominent Egyptian scholar of Islam. She writes that her female Muslim friend in the west had good morals and that their behavior does not remain the same before and after their marriage. She criticizes that fatwa of Dr. Qaradawi shows his prejudice against the West.

Iman Akama is a modern intelligent woman with Islamic knowledge. She has also had experience of living both in the West and in the Muslim 
society in Syria, so that she has been able to find that the discussion by Dr.Qaradawiy in this book is based on the image that is not actual or real.

Many Japanese think that scholars of Islam have absolute power and influence on the Islamic society and that nobody can express any views against them. In a sense it is true, and in another sense, it is not. Women today should express their questions freely to scholars of Islam, like Akama has done, after considering tense relations between the West and the Arabs in the past and in the Palestinian issues.

\section{【 No.7】}

Matsumoto, Fatimah (2013) "Maa shallah in Saudi Arabia - insight eye and a strange experience of a Japanese woman married with a Saudi and their family life" 239 pages, Korokara, Japan

ファーティマ松本( 2013)『サウジアラビアでマッシャアラー! 嫁いでみたアラブの国の不思議本験 、239頁、ころから

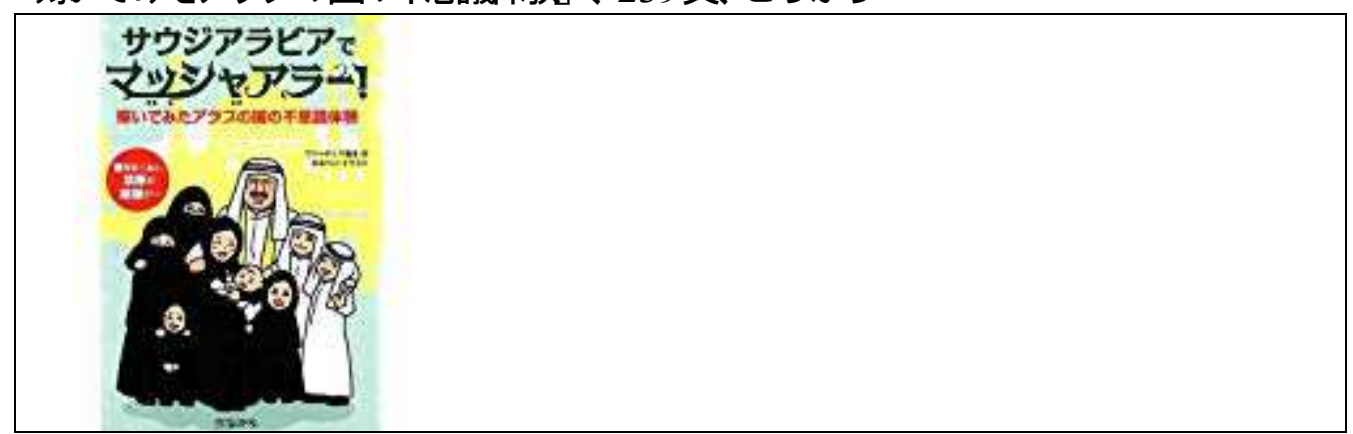

Fatimah Matsumoto began her marriage life in Madina city in 1995 with a husband of Egyptian origin with a Saudi nationality. It was six years later after submitting an application for a certificate of the official marriage permit. They have two sons and five daughters. She may by now have grandchildren (P.14).

She became acquainted with him in the US when she was 18 years old. She studied English in the state of Louisiana. She was young and naïve, believing that she could live anywhere if she is with a husband she loves. She says that the US Christians were very kind to her when she participated in activities in church. However, her husband intervened and tried to persuade how Christianity was wrong, hiding his true feelings that he wanted to make friends with her. He used complicated theological problems of the Trinity. It seems to me that her husband did not have historical or theological understanding, but he succeeded in persuading a 18-year-old Japanese girl, who later became his Muslim wife (pp.203-210). 
رسالة المشرة

15

Fatimah Matsumoto and her husband made a marriage contact in Islamic Center in the US. The staff members there advised her to get Mahar as they do in Saudi Arabia and to demand several conditions, such as the abandonment of the right to marry someone other than her, from her husband. The pieces of the advice they were able to provide for her were fruits of Islamic jurisprudence. They were the outcomes achieved through the efforts of Islamic Scholars to harmonize what Islamic Law stands for with what the modern society stands for to protect the human rights (pp.23-30). At first, Fatimah Matsumoto did not realize the importance of demanding such conditions on her husband, and the 18-year-old Japanese girl were not interested and practically ignored the advice.

Fatimah Matsumoto introduced many episodes from her own experience in the Saudi Arabian society.

She provides one type of cultural comparison here between Islam and Japan. Bellow are some of the captions of the chapters in the book;

1) Not so easy to be married to foreigners

2) Many youths staying unmarried

3) Divorce during menstruation being unlawful.

4) Sons rather than daughters

5) The meaning of Maa shaallah

6) Mother of her husband: an obstacle in marriage life

7) Husband preparing for the second marriage without any notice to his wife, his excuse being that the purpose of the second marriage was to take care of the aged his mother.

8) About Islam, Japanese people and Islam...etc.

【 No.8】 My experience of teaching Islam in classes at university

Finally, I would like to present to you my own experience, while at the same time making some comments on the views in the books introduced so far in this paper

One of the classes I teach is titled "Religions in the World," and I once had a report submitted for the class by a student whose father is a born Muslim from Morocco and whose mother is a Japanese Muslim woman.

He is a student in the Faculty of Law in our university. His report was as follows as;

"I understood something about Islam after attending the lecture by Prof. Shinohe. My father is a born-Muslim from Morocco. Islam has always been in my family, but he ate pork, drunk beer, smoked cigarette, and did not pray 
regularly until three years ago. And then he suddenly changed. He began to pray regularly and to practice fasting, and he stopped eating pork or drinking beer. What happened to him? I thought that it was too late to repent to Allah after having betrayed the teaching of Islam.

Today I understood that his action of repentance was based on Quran and Sunna, and that in Islam repentance by the believers is accepted unconditionally at any time until his death or the Day of Judgement. There is no punishment in this world we presently live. Allah postpones punishment until the Day of Judgement passes."

This student belongs to the $6^{\text {th }}$ generation of Japanese Muslim. In other words, the parents of this generation are Muslims.

History of Islam in Japan began with Japanese men, followed by Japanese women. Today, we can find Japanese born-Muslims from Muslim families who share the Japanese culture and custom.

The prophet PBUH was longing for Makkah, seeing the moon. Belief and love for one's own country do not contradict - they can stand together. Islam in Japan can harmonize with Japanese culture and its custom, and the issue of female clothes will not be an exception. 
رسالة المشرة

17

\section{References}

- Kawata, Naoko (2004) “Introduction to Islam by a Japanese Muslim Woman, " 203 pages, Tukubanesha, Japan

(2011) "Islam and Japanese Women" 250 pages, Kokusho Kankoukai, Japan

- Kobayashi, Akiko (2015) "When Japan Meets Islam - Its History and Future -" 316 pages, Gendai Shokan,Japan

- Skurai Yukiko (2003) “Islamic Society in Japan” 223 pages, Tsikumashobou, Japan

- Sato, Kenei(2015) "Believing in Islam in Japan" 216 Pages, Bungei Shijyu, Japan

- Qradawi, Yusef(2012) “Islamic Jurisprudence for Minority Muslims" translated into Japanese,271pages,.Japan-Saudi Association, Japan

- Matsumoto, Fatimah(2013) "Maa shallah in Saudi Arabia - insight eye and a strange experience of a Japanese woman married with a Saudi and thier family life" 239 pages, Korokara, Japan

Article

- "Islam in Japan” “ News Week, Japanese editon,Vol.19, No.8, 2004/02/25, pp.16-23

- Kawabashi,Noriko \& Komatsu,Kayoko(2016) "Religion and Gender in the Politics - Eye of Anthropology of Gender" 233 pages, Showado, Japan 